A. Nechausovi ${ }^{1}$ I. Mamusuĉ ${ }^{2}$ N. Kuchuk ${ }^{3}$

${ }^{1}$ National Aerospace University - Kharkiv Aviation Institute, Kharkiv, Ukraine

${ }^{2}$ University of Zagreb, Zagreb, Croatia

${ }^{3}$ Vasyl Karazin Kharkiv National University, Kharkiv, Ukraine

\title{
SYNTHESIS OF THE AIR POLLUTION LEVEL CONTROL SYSTEM ON THE BASIS OF HYPERCONVERGENT INFRASTRUCTURES
}

\begin{abstract}
The subject matter of the article is an air pollution control process. The aim is development of proposals for the synthesis of the air pollution control system based on hyperconvergent infrastructures. The objectives are: the development of a mathematical model for constructing pollutants concentration fields; substantiation and development of a conceptual model of the geoinformation system for air pollution control, justification and selection of the basic infrastructure of the control system. The methods used are: system analysis of risks, cause-and-effect analysis, statistical methods. The following results are obtained: The basic influencing on character of dispersion and distribution of harmful substances factors in atmosphere are allocated. A multifactorial mathematical model has been developed for constructing fields of concentration of pollutants, which is based on two types of distribution-the normal and $\mathrm{S}_{\mathrm{L}}$-distribution of Johnson. The geoinformation technology (GIT) structure components are determined. A program for determining the stability class of the atmosphere has been developed. A model of the process under investigation on a cartographic basis was developed with the presentation of the results in the form of a concentration isotype. The structure of the database of the parameters of sources and characteristics of sources of air pollution, which is part of the serving hyperconvergent infrastructure, has been developed. Conclusion. The synthesized air pollution control system will allow to solve such tasks: collection of primary information, its systematization, analysis and formation of a data bank; processing and presentation of data in the form of thematic pollution maps; Assessment of the current state of the environment and forecast; analysis of the causes of observed and probable changes in the state; prompt provision of necessary information to all stakeholders.
\end{abstract}

Keywords : air pollution; control; hyperconvergence; model.

\section{Problem analysis and the research task formulation}

Atmospheric air monitoring systems are an integral part of state municipal complex systems for monitoring the state of the environment. The main goal of these systems is to fulfill the task of ensuring the safety and quality of the environment, developing a strategy and tactics for the work of environmental services, which guarantees obtaining objective information about the state of the environment [1-3]. Among industrial facilities, one of the main pollutants of the atmosphere are thermal power plants (about 30\% of all hazardous emissions to the atmosphere comes from stationary sources), oil and gas complexes and chemical industry.

To implement existing and newly developed multitask mathematical models using factual and cartographic data and to visualize the results of the atmospheric air state calculations in the regions, an automated information system for air pollution monitoring with the ability to visualize the results on a cartographic basis online.

The obvious advantages of automated air pollution control systems are the ability to monitor and forecast changes in the state of atmospheric air. However, for a long time such systems could exist only in the form of calculations of local foci of contamination and could not be used as a full model of the entire situation of the region. The main reason of this was the lack of data collection, storage and distribution technologies capable of servicing large amounts of information in a real time, thus ensuring the interaction between the main functional blocks of complex systems. The next reason was the inadequate development of suitable for the operational use of forecasts for the vertical distribution of meteorological values, which limited the introduction of methods for numerical prediction of air pollution and made it difficult to improve the predictive schemes. The introduction of hyperconvergent [4] systems in the process of creating and maintaining large-scale automated solutions based on interactive web services makes it possible to solve the task $[5,6]$. The purpose of this article is to develop proposals on the synthesis of the air pollution control system based on hyperconvergent infrastructures.

\section{Mathematical model for constructing pollutants concentration fields}

The main requirement for the developing solution is the ability to perform the tasks in real time with the option of fast scanning and increasing the processing power.

The wide possibilities of geoinformational technology together with cloud-systems allow modeling the distribution of pollutants concentration fields on the basis of general indices of industrial facilities operation or other sources of pollution and the level of their impact on the environment in real time [7].

For heat and mass transfer process analysis results upon ejection gas mixture major influencing factors on the nature of the diffusion and propagation of harmful substances in the atmosphere were highlighted (Fig. 1) and based on this, a multifactorial mathematical model (1) to construct the concentration of contaminating fields substances which is based on two types of distribution - normal (for a description of dispersion of pollutants in the vertical plane and $\mathrm{Y}$ axis perpendicular 
to the axial flow path) and Johnson SL- distribution (for hell suitable approach approximation asymmetric concentration profile along the axis $\mathrm{X}$ of the wind direction) was created (Fig. 2):

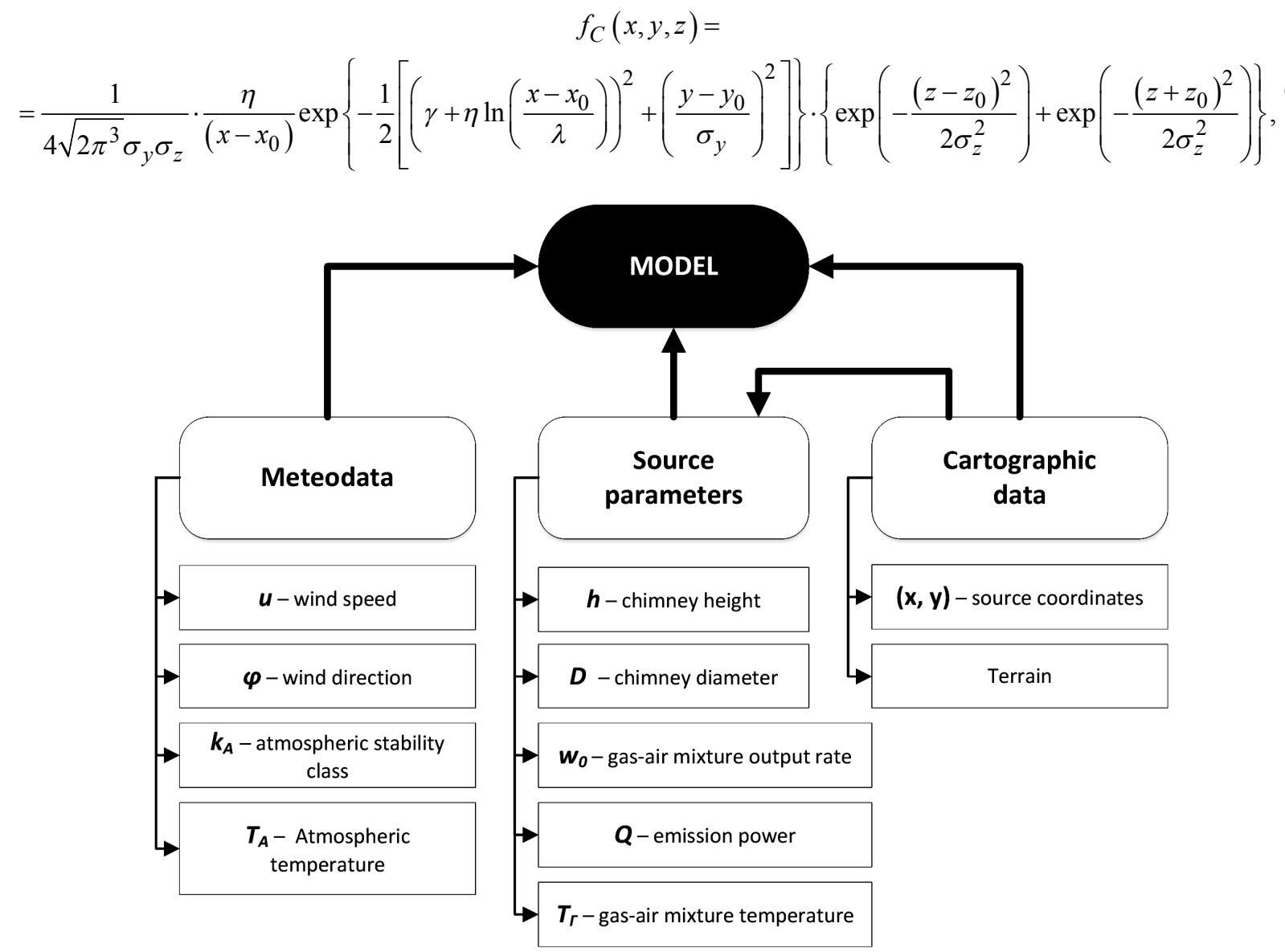

Fig. 1. The major factors affecting the nature of dispersion and movement of harmful substances in the atmosphere considered in the model

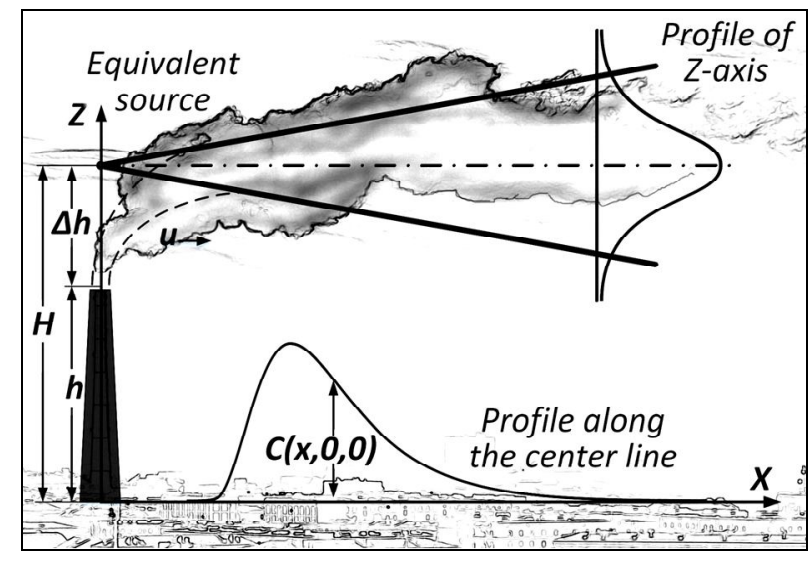

Fig. 2. Physics of the heat and mass transfer process illustration as a basis of multivariate mathematical model for constructing pollutants fields of concentration

where $x_{0}, y_{0}, z_{0}-$ spatial coordinates of the virtual pollution source; $x_{0} \equiv \varepsilon$ and $\lambda(\lambda>0)$ - scale parameters of $\mathrm{S}_{\mathrm{L}}$ - Johnson distribution; $\eta$ and $\gamma$ - parameters of $\mathrm{S}_{\mathrm{L}}$ Johnson distribution form; $\sigma_{y}$ and $\sigma_{z}-$ standard deviation (SD), which characterize the scattering of pollutants along the corresponding axes.

Effective source height $H \equiv z_{0}$ is defined as the sum of the geometric height of the chimney $h$ and the initial rise of the jet $\Delta h$ :

$$
\Delta h=3,75 w_{0} R_{0} / u+(1,6 g V \Delta T) / T_{A} u^{3},
$$

where $w_{0}$ - gas velocity at the source outlet, $\mathrm{m} / \mathrm{s} ; R_{0}-$ jet radius, $\mathrm{m} ; \mathrm{u}$ - wind speed, $\mathrm{m} / \mathrm{s} ; V$ - volume of exhaust gas, $\mathrm{m}^{3} / \mathrm{s} ; \Delta T-$ overheating of gas relative to ambient air, ${ }^{\circ} \mathrm{K} ; T_{A}$ - atmospheric temperature, ${ }^{\circ} \mathrm{K}$.

Thematic information concerning the location and configuration of the main sources of environmental pollution should be provided by appropriate electronic maps. In related tables, it is useful to store general information about the enterprises of the region and the pollutants.

Thus, the structure of geoinformation technology should include the following interrelated links:

- database (DB) of environmental, meteorological, regulatory, sanitary-hygienic, technical and economic aspects;

- block of modeling and statistical analysis of results;

- block for the formation and forecast of the spread of the pollutant concentrations fields for nonstationary meteorological factors and taking into account the finite time of the functioning of emission sources;

- a block of managerial decisions making support;

- an online data distribution system 


\section{Geoinformation system for air pollution control}

In order to automatically readed data from meteorological resources and determine the atmospheric stability classes on a continuous basis and transmit these data to storage and modeling units, a corresponding program based on the Pasquill table was developed (Fig. 3).

After calculating the local levels of atmospheric pollution, it becomes necessary to present the results of modeling in the form of the harmful substances concentration isotope on a cartographic basis in vector form with georeferencing.

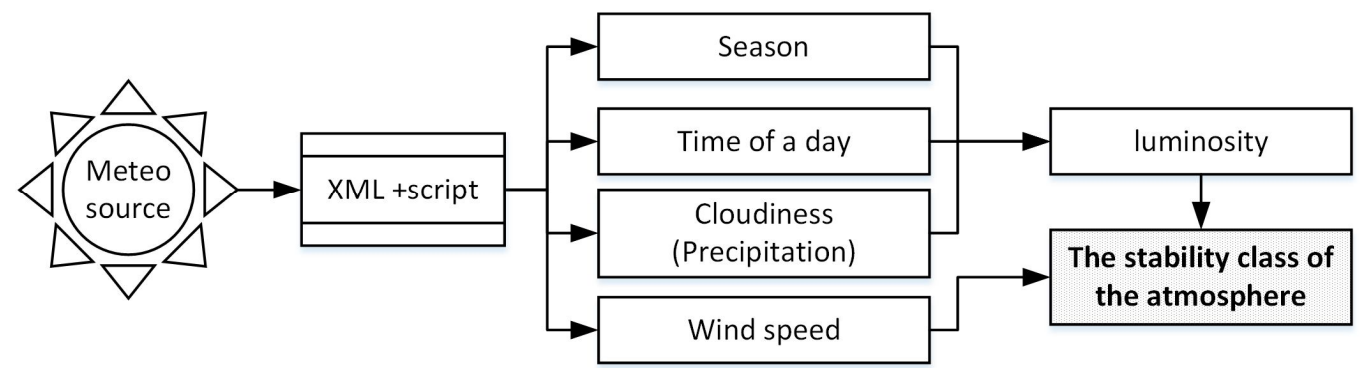

Fig. 3. Structural diagram of the program for determining the stability class of the atmosphere

For this purpose, a procedure (Fig. 4), implemented in the DECartesian program, was developed.

The algorithm of the program is conditionally divided into 2 functional blocks: 1 - the block of the concentration isotope contour points search. To do this, the fragment of the map is segmented into squares of the matrix with various average concentrations of pollutants, after which each square is assigned with a hazard level (determined by exceeding the maximum permissible concentration) (Fig. 5).

This level can vary with the inclusion of harmful substances from different sources. The final level of danger is calculated by the superposition method (4) of matrices from different sources located in the radius of contamination of each other. The second block is the unit for converting Cartesian coordinates into geographical coordinates, as a result of which a text file with geographic coordinates of the isople points is created.

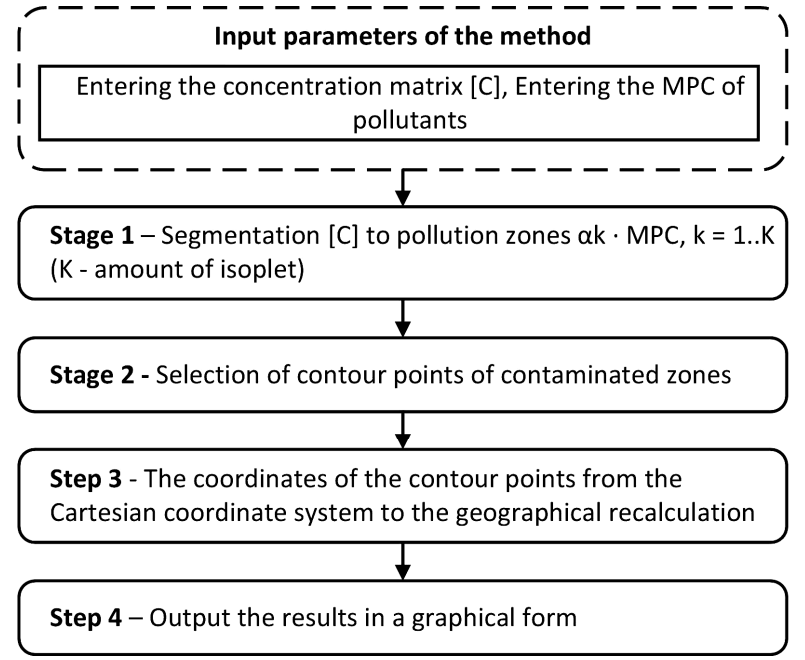

Fig. 4. The procedure for presenting the results of modeling the pollutants concentration fields in the form of contaminated zones on a cartographic basis

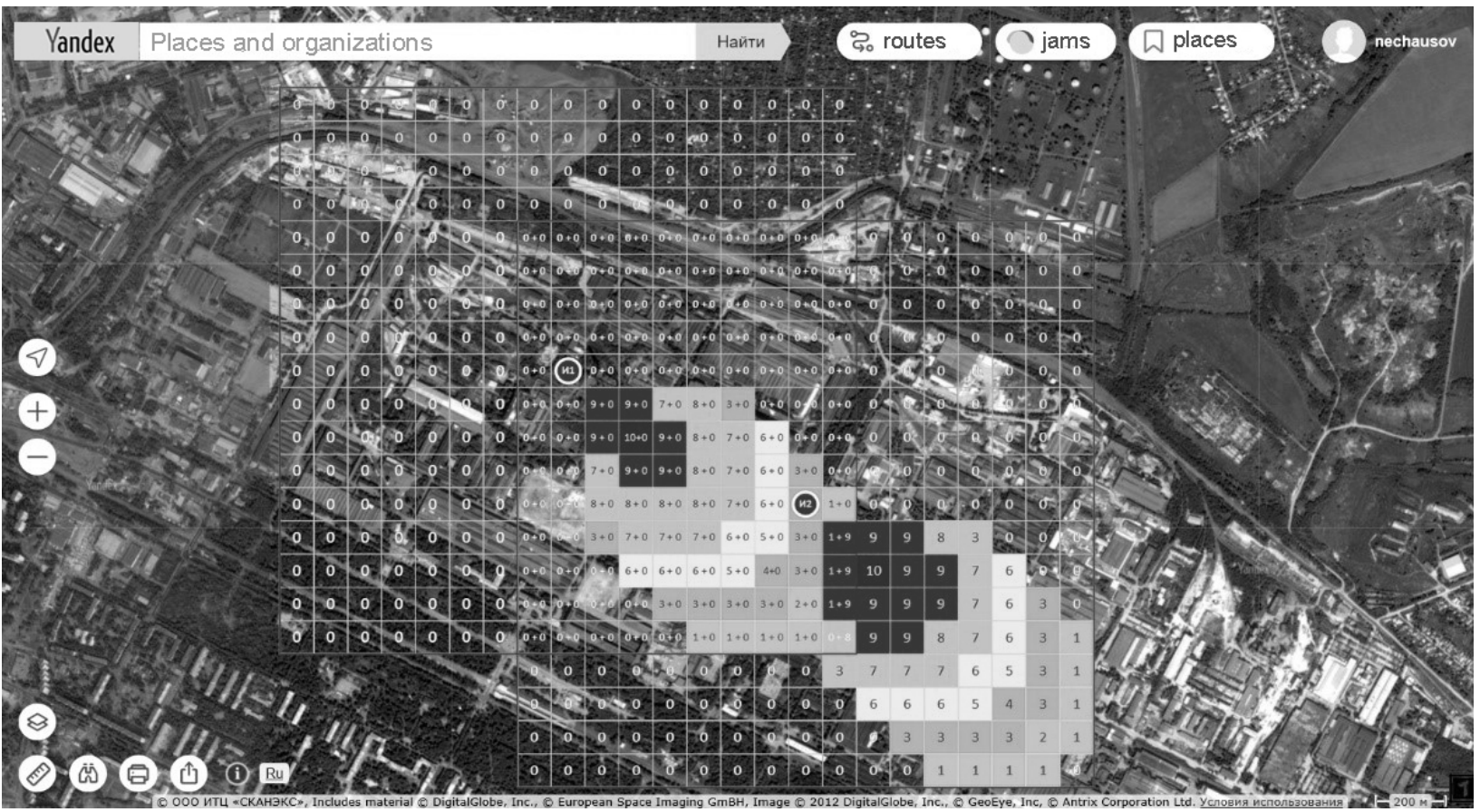

Fig. 5. The principle of applying matrixes of pollutants concentration on a cartographic basis 
The final view of the working field of the visualization unit with the window for the simulation parameters setting and the results of constructing the non-stationary concentration field is shown in Fig. 6.

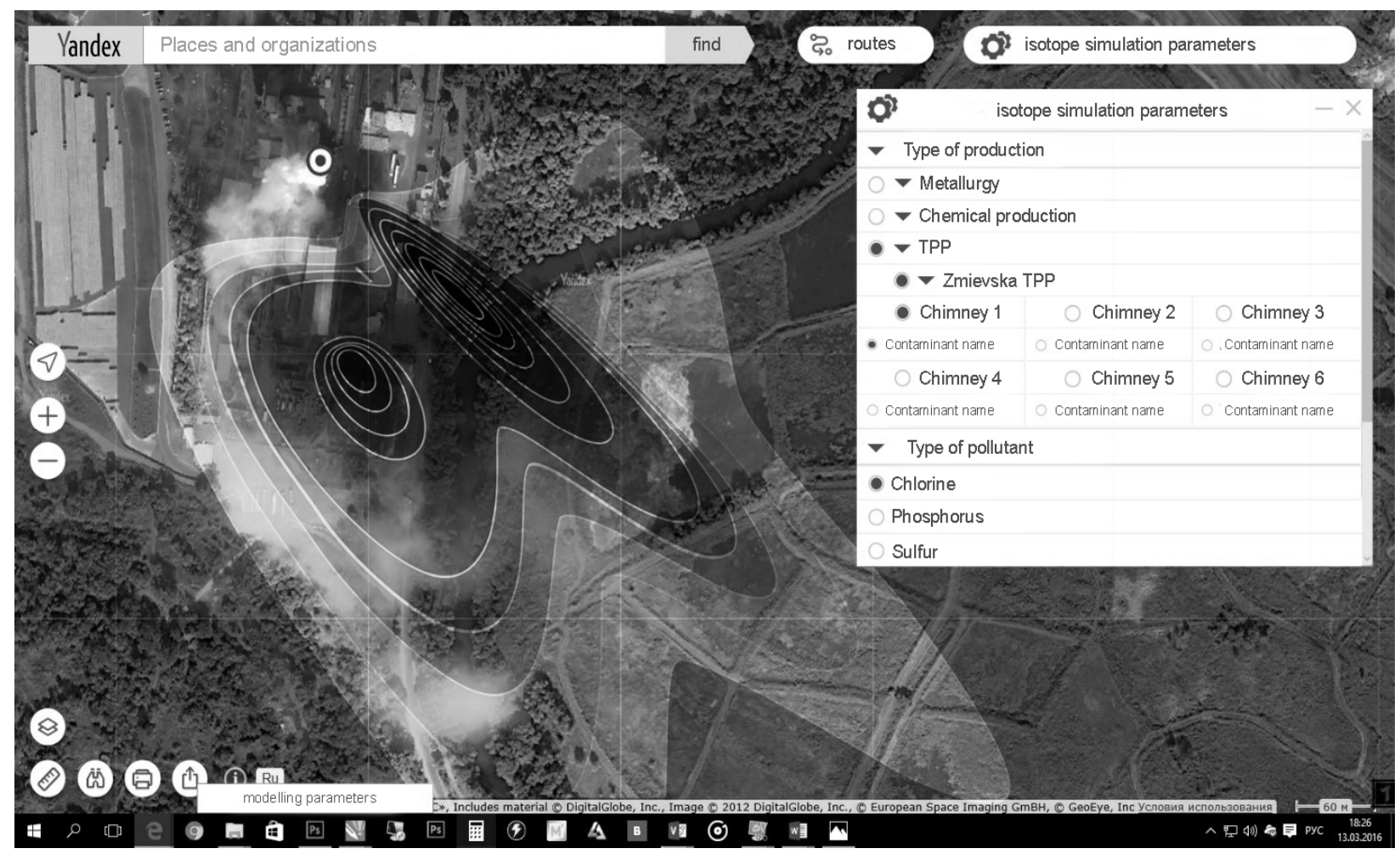

Fig. 6. Displaying simulation results on a cartographic basis in the form of an isotope concentration

The YandexMaps ${ }^{\circledR}$ API was used to build the state map, in addition, GoogleMaps ${ }^{\circledR}$ or GoogleEarth ${ }^{\circledR}$ technology can be used.

These services are open resources and can be used to visualize various thematic data. To store observational data (in the current time interval $t_{J}$ ) and corresponding fields of pollutant concentrations in the surface layer of the atmosphere, a remote temporary data storage is needed, which is part of the serving hyperconvergent system.

All the factors and input data necessary for determining the concentration of contamination are taken into account and reflected in the conceptual model of GIT [8] (Fig. 7).

The basis of this model are the outlined above functional units that somehow interact with the functional core and the serving hyperconvergent system, which allows to carry out the data traffic necessary for the timely provision of input data to all the geoinformation technology blocks and transmission of the results of these blocks, allowing to build long-term forecasts and collect and the analysis of statistical data for several years.

The second, no less important element of GIT, is the database of industrial enterprises in the region (Fig. 8), which is part of the serving hyperconvergent infrastructure.

It proposes to store attributive descriptions of enterprises: the industry, the composition of emissions into the atmosphere, the height $h_{i}$ and the diameters of the pipes $D_{i}$, the power of the ejection $Q$, the velocity of the gases $w_{0}$ at the outlet of the source, the temperature of the thrown out gas-air mixture $T_{\Gamma}$; values of parameters $Q, w_{0}, T_{\Gamma}$ are established according to the current technological standards for the given production.

The values of the daily concentration fields for the monitored territory or monitored objects, as well as the fields of the measured meteofactors with the date of observations are transferred to the resulting data remote store of the serving hyperconvergent system.

An important and necessary feature of such a maintenance system is the use of modern technologies for replicating information, which allows you to restore data in the event of an emergency.

\section{Conclusions}

Thus, the proposed control of air pollution the geoinformation technology will solve such problems:

- collection of primary information, its systematization, analysis and formation of a data bank;

- processing and presentation of data in the form of thematic pollution maps;

- assessment of the current state of the environment and forecast;

- analysis of the causes of observed and probable changes in the state;

- prompt provision of necessary information to all stakeholders.

Direction of further research: selection of the characteristics and structure of the Hardware and Software hyperconvergent platform for the proposed system. 


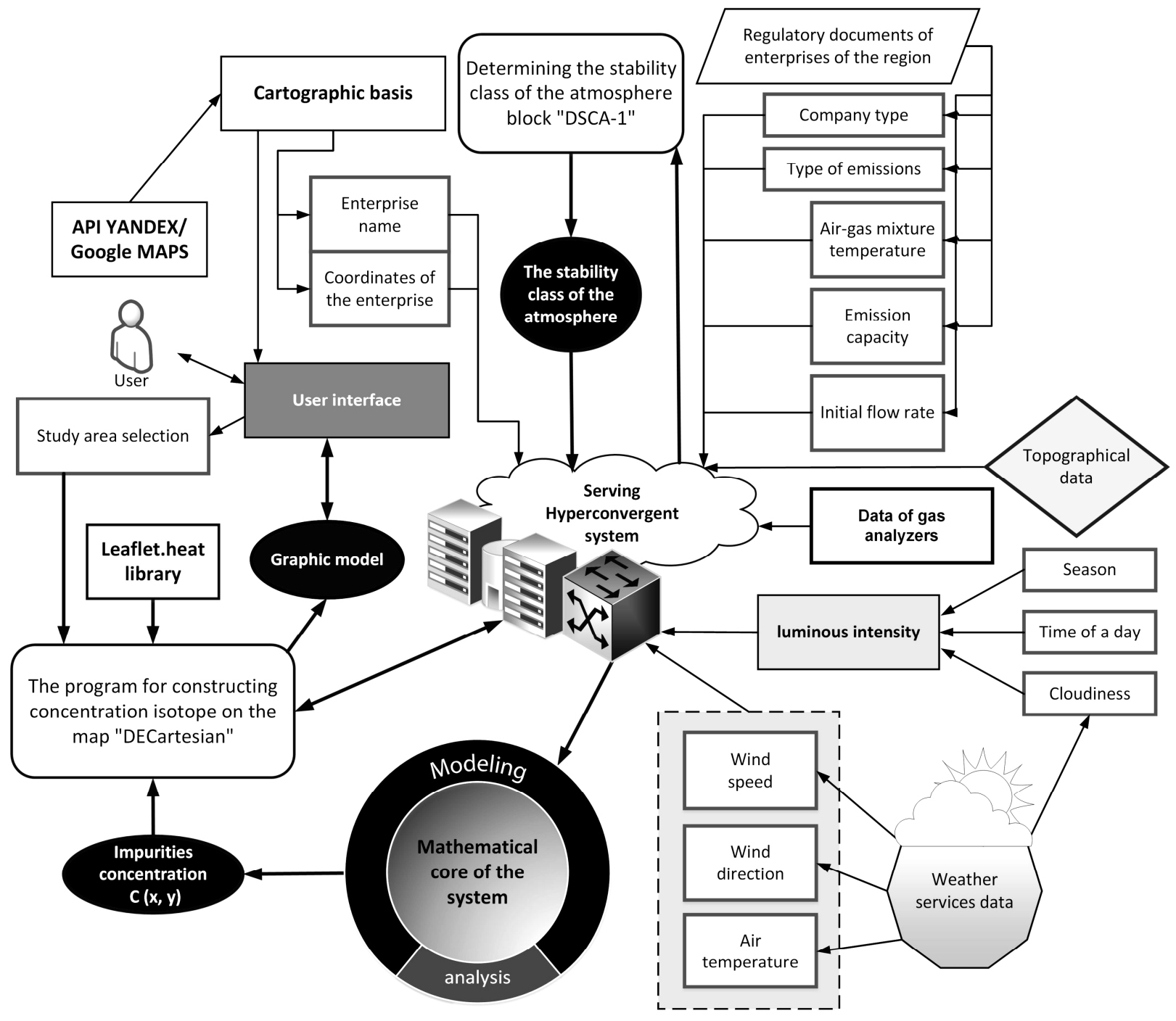

Fig. 7. The atmospheric air pollution control GIT conceptual model

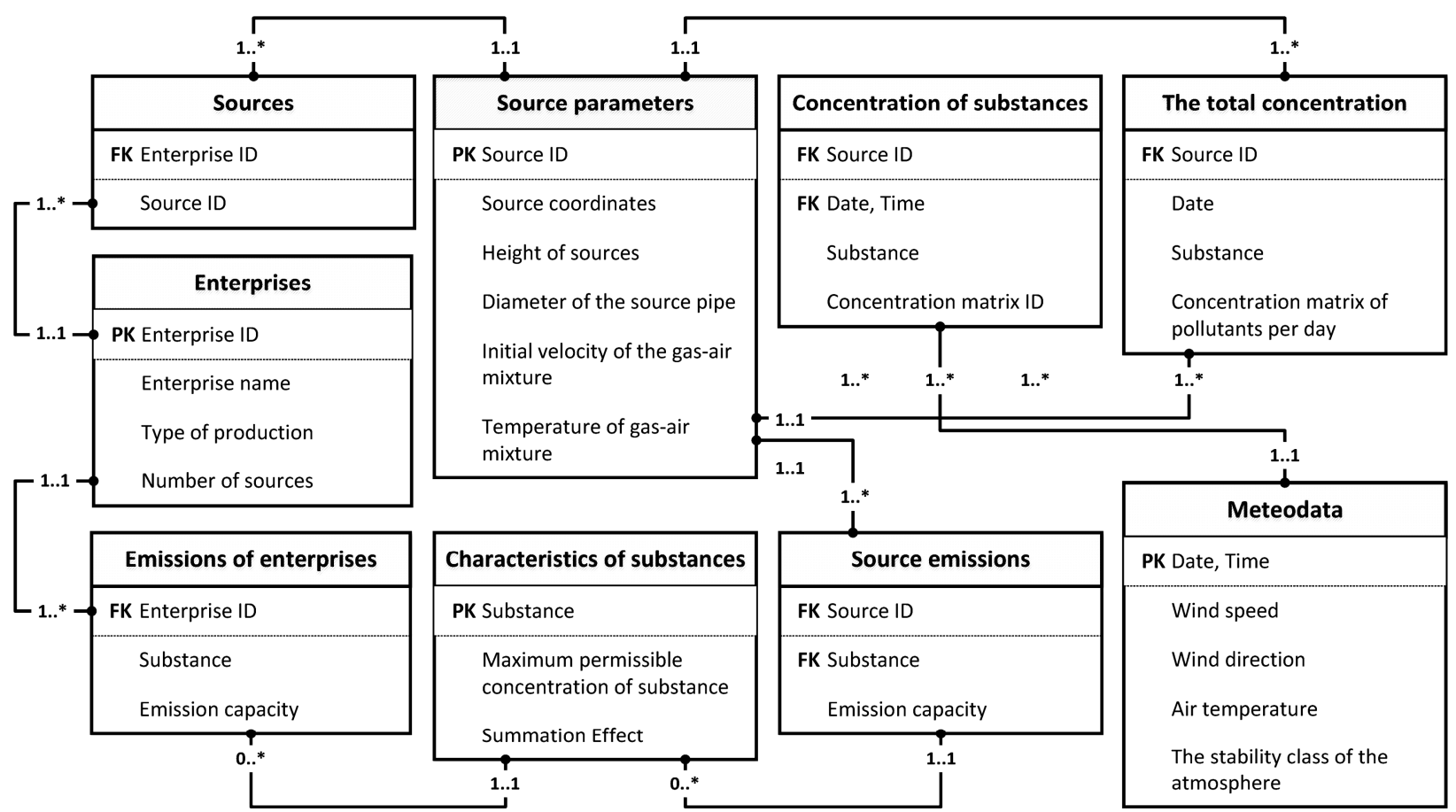

Fig. 8. Database of source parameters and contaminants characteristics structure 
REFERENCES

1. Kobtseva, N.Yu. and Ermolenko, B.V. (2012), The analysis of existing mechanisms of regulation of influences users on a condition of atmosphere and planned way soft heir perfection, Scientific Journal for Alternative Energy and Ecology, No. 03 (107), pp. 5-12.

2. Priputina, I.V. and Bashkin, I.V. (2012), "Ekologicheskiye riski v svyazi s tekhnogennym zagryazneniyem okruzhayushchey sredy: analiz podkhodov i metodov otsenki" [Ecological risks in connection with technogenic pollution of the environment: an analysis of approaches and methods of assessment], Problemy analiza riska [Problems of risk analysis], No. 5. pp. 12-25.

3. Gorelik, D.O. and Konopelko, L.A. (1992), Monitoring zagryazneniya atmosfery i istochnikov vybrosov. Aeroanaliticheskiye izmereniya [Monitoring of air pollution and emission sources. Aerial analytic measurements], Publishing house of standards, Moscow, $432 \mathrm{p}$.

4. Ganja, D (2016), Hyperconvergence: IT infrastructure at times, two, three", Zhurnal setevykh resheniy [Network Solutions Journal], No. 5, available at: www.osp.ru/lan/2016/05/13049349 (accessed April 23, 2017).

5. White Paper: Riverbed Hyper-converged Edge, available at: https://www.riverbed.com/document-repository/ white-paper-riverbed-hyper-converged-edge.html (accessed April 23, 2017).

6. Kuchuk, G., Kharchenko, V., Kovalenko, A. and Ruchkov E. (2016), “Approaches to Selection of Combinatorial Algorithm for Optimization in Network Traffic Control of Safety-Critical Systems", Proceedings of IEEE East-West Design \& Test Symposium (EWDTS'2016), pp. 384-389.

7. Vasilyeva, I.K. and Nechausov, A.S. (2016), "Struktura sistemy ekomonitoringa na osnove veroyatnostnoy modeli lokalnogo zagryazneniya atmosfery" ["The structure of the ecomonitoring system based on the probabilistic model of local atmospheric pollution"], Systemy obrobky informatsiyi [Information Processing Systems], No. 1(138), pp. 176-182.

8. Nechausov, A. (2016), "The information model of the system for local atmospheric air pollution monitoring", Systemy obrobky informatsiyi [Information Processing Systems], No. 2(139), pp. 190-195.

Надійшла (received) 12.05.2017

Прийнята до друку (accepted for publication) 04.10.2017

\title{
Синтез системи контролю рівня забруднення повітря на базі гіперконвергентних інфраструктур
}

\author{
А. С. Нечаусов, І. Мамусич, Н. Г. Кучук
}

Предметом вивчення в статті $\epsilon$ процеси контролю рівня забруднення повітря. Мета - розробка пропозицій по синтезу системи контролю рівня забруднення повітря на базі гіперконвергентних інфраструктур. Завдання: розробка математичної моделі для побудови полів концентрації забруднюючих речовин; обгрунтування і розробка концептуальної моделі геоінформаційної системи контролю забруднення повітря, обгрунтування і вибір базової інфраструктури системи контролю. Використовуваними методами є: системний аналіз, статистичні методи, причиннонаслідковий аналіз. Отримані такі результати. Виділено основні впливові фактори на характер розсіювання i поширення шкідливих речовин в атмосфері. Розроблено багатофакторна математична модель для побудови полів концентрації забруднюючих речовин, яка грунтується на двох типах розподілу - нормальному і SL- розподілі Джонсона. Визначено компоненти структури геоінформаційної технології. Розроблено програму визначення класу стабільності атмосфери. Розроблено модель досліджуваного процесу на картографічній основі $з$ поданням результатів у вигляді ізоплет концентрації. Розроблено структуру бази даних параметрах джерел і характеристиках джерел забруднення повітря, яка входить до складу обслуговуючої гіперконвергентной інфраструктури. Висновки. Синтезована система контролю забруднення повітря дозволить вирішувати такі завдання: збір первинної інформації, іiі систематизація, аналіз та формування банку даних; обробка та представлення даних у вигляді тематичних карт забруднень; оцінка поточного стану навколишнього середовища і прогнозу; аналіз причин спостережуваних та ймовірних змін стану; оперативне забезпечення необхідною інформацією всіх зацікавлених осіб.

Кл юч ов і сл ов а : забруднення повітря; контроль; гіперконвергентность; модель.

\section{Синтез системы контроля уровня загрязнения воздуха на базе гиперконвергентных инфраструктур}

\section{А. С. Нечаусов, И. Мамусич, Н. Г. Кучук}

Предметом изучения в статье являются процессы контроля уровня загрязнения воздуха. Цель - разработка предложений по синтезу системы контроля уровня загрязнения воздуха на базе гиперконвергентных инфраструктур. Задачи: разработка математической модели для построения полей концентрации загрязняющих веществ; обоснование и разработка концептуальной модели геоинформационной системы контроля загрязнения воздуха, обоснование и выбор базовой инфраструктуры системы контроля. Используемыми методами являются: системный анализ, статистические методы, причинно-следственный анализ. Получены следующие результаты. Выделены основные влияющие факторы на характер рассеивания и распространения вредных веществ в атмосфере. Разработана многофакторная математическая модель для построения полей концентрации загрязняющих веществ, которая основывается на двух типах распределения - нормальном и SL- распределении Джонсона. Определены компоненты структуры геоинформационной технологии. Разработана программа определения класса стабильности атмосферы. Разработана модель исследуемого процесса на картографической основе с представлением результатов в виде изоплет концентрации. Разработана структура базы данных параметрах источников и характеристиках источников загрязнения воздуха, которая входит в состав обслуживающей гиперконвергентной инфраструктуры. Выводы. Синтезированная система контроля загрязнения воздуха позволит решать такие задачи: сбор первичной информации, ее систематизация, анализ и формирование банка данных; обработка и представление данных в виде тематических карт загрязнений; оценка текущего состояния окружающей среды и прогноза; анализ причин наблюдаемых и вероятных изменений состояния; оперативное обеспечение необходимой информацией всех заинтересованных лиц.

Ключевы е слов а : загрязнение воздуха; контроль; гиперконвергентность; модель. 